\title{
Performance of Six Bivoltine Bombyx mori (Lepidoptera: Bombycidae) Silkworm Strains in Kenya
}

\author{
E.K. Nguku ${ }^{* 1,2}$, V.V. Adolkar ${ }^{1}$, S.K. Raina ${ }^{1}$, K.G. Mburugu ${ }^{2}$, O.M. Mugenda ${ }^{2}$ and D.M. Kimbu ${ }^{1}$ \\ ${ }^{1}$ International Center of Insect Physiology and Ecology, P.O. Box 30772 - 00100, Nairobi Kenya \\ ${ }^{2}$ Kenyatta University, P. O. Box 42844 - 00100, Nairobi Kenya
}

\begin{abstract}
The economic and field performance of six Bombyx mori Linnaeus bivoltine strains were evaluated, namely ICIPE I, Chun-Lei X ZhengZhu (C X Z), QuiFeng X BaiYu (Q X B), Quingsong X Haoyoe (Q X H), Suju X Minghu (S $X \mathrm{M}$ ) and 75xin X 7532 (75xin). Performance was based on larval, cocoon, pupa and shell weights, relationship of food consumption to larval weight, cocoon weight and shell weight. ICIPE I recorded the shortest larval development period in Location 1 (S1) during the short rains (SR) $(26.53 \pm 5.05$ days) and it was significantly shorter compared to that of the other strains. It also had the highest cocoon shell weight (CSW) in location 1 (S1) and location 2 S2), 0.38 and 0.36gms respectively. ICIPE I and C X Z strains gave better performance for the parameters evaluated and are most suitable for the Kenyan conditions.
\end{abstract}

Keywords: Silkworm (Bombyx mori), larval duration, larval weight, cocoon weight, pupa weight, shell weight.

\section{INTRODUCTION}

The common silkworm Bombyx mori Linnaeus (Lepidoptera: Bombycidae) spins valuable silk fibre, making it one of the most beneficial insects to mankind, and is becoming an attractive multifunctional material for both textile and nontextile uses [1]. Almost all-commercial silk is made from cocoons spun by silkworms of the genus Bombyx [2].

Rearing of high-quality silkworm varieties that adapt to the local environment is an important method for improving cocoon quality, increasing cocoon yield and enhancing profit. Differences in climatic conditions of different agroecological across the regions, including the significant distinctions in temperature, humidity and the significantly different silkworm-rearing environment in different seasons, require that the silkworm variety should be both hypersilkgeneous and adversity resistant [3].

Rearing performance in silkworms is affected by ecological, biochemical, physiological and quantitative characters, which influence growth and development, quantity and quality of silk they produce in different geographical locations $[4,5,6]$. Its success depends on the various factors including successful implementation of technological and managerial tools along with high yielding best-suited mulberry and silkworm varieties $[7,8]$. In addition, the $B$. mori insect is an oligophagous herbivore and depends mainly on the quality of mulberry leaves and environmental conditions for its development [9].

The steadily growing demand for silk in the silk consuming countries indicates excellent opportunities for any country to increase her silk production [11], a valuable opportunity, for Kenya to embark on. In order to secure this oppor-

*Address correspondence to this author at the International Center of Insect Physiology and Ecology, P.O. Box 30772 - 00100, Nairobi Kenya;

E-mail: enguku@icipe.org tunity, it is consequently important to establish the performance of the silkworm strains available.

In recent years, farmers in Kenya among other African countries have initiated mulberry silkworm rearing. However, appropriate selection of the silkworms strains based on rearing performance and economic qualities in different climatic conditions is essential to select and exploit suitable silkworm strains for improved sericulture practices [10].

Mulberry sericulture being almost a new venture in this region depends to a large extent on the introduced breeds and the stability of silk industry greatly depends on the locally adapted breeds.

It is with this background that this study evaluates the performance of six selected silkworm strains, namely: Chun Lei X Zen Zhu (C X Z), Quifeng X Baiyu (Q X B), Quingsong X Haoyoe (Q X H), Suju X Minghu (S X M), 75xin X 7532 (75xin) and ICIPE I, with the aim of identifying a suitable silkworm strain for enhanced cocoon production in Kenya and other countries in the region, where this activity is increasingly perceived as a promising alternative source of income generation for rural small-scale farmers. This information is vital for suitable management of healthy silkworms, improvement of silkworm strains and production of high quality cocoons.

\section{MATERIALS AND METHODS}

\section{Research Location}

Silkworm rearing was conducted in two locations at ICIPE's Duduville Campus, Nairobi, which is located between $1^{\circ} 18^{\prime} \mathrm{S}$ and $36^{\circ} 49^{\prime} \mathrm{E}$. The altitude is $1798 \mathrm{~m}$ above sea level. ICIPE's Commercial Insects Programme (CIP) laboratories were selected as the first location (S1), and the second (S2) was at the CIP field site (makuti farm). Rearing was done during two seasons, the long rains (LR) and the short rains (SR). 


\section{Experimental Insect}

Disease-free egg layings (dfls) of the bivoltine silkworm hybrids, C X Z, Q X B, Q X H, S X M, 75xin and ICIPE I strains were used in this investigation. Rearing of all the silkworms was done following the procedures of [12, 13]. Silkworms in $S 1$ were reared under standard conditions $26 \pm 2{ }^{\circ} \mathrm{C}, 70 \pm 5 \% \mathrm{RH}$ and 12:12 (L:D) photoperiod, according to [14]. Rearing was done in trays measuring $90 \times 60 \mathrm{~cm}$, placed on rearing racks, $150 \times 75 \times 200 \mathrm{~cm}$ that could hold 24 trays each. The silkworm larvae were reared in these trays from their first instar to the fourth. At the onset of the fifth instar, 100 worms of each strain were randomly selected and monitored individually. They were placed in trays that were partitioned into small compartments measuring $10 \times 10 \times 10$ $\mathrm{cm}$ and reared under these same conditions.

Location $S 2$ was a demonstration site with facilities similar to those that would be available to the rural silk farmer. Temperature and humidity in the room ranged between 24 $27{ }^{\circ} \mathrm{C}$ and $84 \%-86 \%$ respectively for young age rearing and $23-24{ }^{\circ} \mathrm{C}$ and $65 \%-70 \%$ respectively for late age rearing and 12:12 (L:D) photoperiod. Rearing was done on a threetier shoot rearing rack measuring $15^{\prime} \times 5^{\prime} \times 8^{\prime}$ and accommodates up to 15,000 worms. In the fifth instar, 100 larvae of each strain were selected randomly, placed in permeable paper pockets, measuring $10 \times 10 \times 10 \mathrm{~cm}$, which were numbered and arranged on the rearing bed for individual monitoring and reared under these same conditions.

\section{Food Plant and Consumption}

Mulberry leaves, which form the only feed for the silkworm larvae $[15,16]$ were used. Kanva-2/M5 (M. alba L) mulberry variety were used for this study and it was established on a 1 acre ( 0.4 ha) farm at icipe's HQ. in Nairobi, Kenya, which experiences four seasons: The warm dry season from January to February, the "long rains" season between March and May with a peak in April, the cool dry season spanning from July to September with a peak in July, and the "short rains" season from October to December with a peak in November. During the study period temperature ranged from high of $25{ }^{\circ} \mathrm{C}$ and average low of $16{ }^{\circ} \mathrm{C}$; relative humidity was an average of $83 \%(\mathrm{am})$ and $51 \%(\mathrm{pm})$.

The mulberry was planted in a row system with 3' by 3' spacing. About 7 tons of manure/ha were applied and mixed well in the rows. The ring method was used to administer a booster dose of urea at 5-7 g/plant, 35 days post-pruning. After each application, the plot was irrigated [9].

For young-age rearing (first to third instar) only tender leaves were used. These were collected from the top portion of the plant and sufficiently nourished the larvae. For lateage rearing (fourth and fifth instar), mature mulberry leaves were used [17].

Food ingested by the silkworm is digested in the alimentary canal and then absorbed into the body. The amount of food not digested is emitted as faecal matter. By subtracting the amount of faeces from the mulberry leaves consumed, the amount of food ingested was estimated [18]. Fifth instar silkworms in $S 1$ and $S 2$, which were reared in isolation, were monitored on a daily basis. The larvae, faecal matter, fresh feed and unconsumed mulberry were weighed daily and recorded. A comparison of the average larval weight (LW) and average weight of the consumed food $(\mathrm{CF})$ from the two locations (S1 \& S2) was done. Weight of the CF was calculated as a percentage of the average LW to verify the relationship between larval weight and amount of food consumed [18].

\section{Cocoon Sorting}

Freshly spun cocoons from the six strains reared in the two locations were harvested from the mountages, sorted and weighed individually on a Kindletec electronic balance model BB 300. Testing for the cocoon layer and pupa weights was done by cutting open the cocoons using a blade to release the pupa and the moulted skin. These were then weighed separately. Weighing the cocoon shell only realized the cocoon layer weight.

\section{RESULTS}

\section{Larval Development and Characteristics}

It was observed that upon hatching, the silkworm larvae of all strains were a gray-black colour, however on reaching the third instar this changed to an off-white color. In this study, the newly hatched larvae of all strains stayed close to the eggshells and did not move around much after hatching. This nature persisted even in advanced stages of the larvae.

There were significant variations in larval duration among the silkworm strains and rearing conditions/seasons. ICIPE I recorded significantly short $(\mathrm{F}=12.61 ; \mathrm{df}=71 ; \mathrm{P}=$ 0.05 ) larval development period in $S 1$ during $S R$ compared to that of the other strains. However, it was not statistically different to that of the $\mathrm{C} \mathrm{X} \mathrm{Z}$. Varying larval development periods were recorded in all strains during $S R$ in $S 2$, however the performance of the strains was not significantly different with an exception of ICIPE I and S X M. The two strains had significantly different larval periods, with ICIPE I recording the shortest and SXM the longest larval periods, $29.77 \pm$ 5.56 and $33.30 \pm 6.19$ days respectively.

During $L R$ in $S 1$ significantly different larval periods were recorded $(\mathrm{F}=8.54 ; \mathrm{df}=71 ; \mathrm{P}=0.05)$. ICIPE $\mathrm{I}$ and $75 x i n$ strains had significantly shorter larval periods $(28.40 \pm$ 5.27 and $28.50 \pm 5.24$ days) compared to QXH and SXM strain $(32.37 \pm 6.01$ and $33.47 \pm 6.21$ days $)$ respectively. All the six strains had shorter developmental larval periods in $S 1$ compared to $S 2$. The differences were statistically different in some cases. However during $L R$, larval development periods of all the six strains did not have statistically significant differences under $S 2$. Within the same strain, the larval durations were not significantly different in the two seasons and locations apart from ICIPE I and S X M. (Table 1).

\section{Weight of Larvae in Relation to Consumed Food}

Amount of food consumed was reflected in the larval weight. The silkworm larvae were able to convert high percentages of food into their own body weight. These percentages ranged between 85.21 and $88.55 \%$ in $S 1$ and 85.19 and $87.67 \%$ in $S 2$. In location $S 1$, average amount of food consumed as a percentage of average larval weight was slightly higher across the strains compared to location $S 2$. ICIPE I was able to convert the highest percentage of consumed food into its weight, 88.55 and $87.65 \%$ for locations $S 1$ and $S 2$ respectively, while Q X $\mathrm{H}$ and $75 x$ in had the least percentages in both locations (Table 2 ). 
Table 1. Average Larval Duration in Location 1 (S1) and Location 2 (S2) During Short Rains (SR) and Long Rains (LR)

\begin{tabular}{|c|c|c|c|c|c|c|}
\hline \multirow{2}{*}{$\begin{array}{c}\text { Season/ } \\
\text { Location }\end{array}$} & \multicolumn{6}{|c|}{ Strain } \\
\cline { 2 - 7 } & ICIPE I & CXZ & $\mathbf{7 5 x i n}$ & QXH & QXB \\
\hline \hline SRS1 & $26.53 \pm 5.03 \mathrm{aA}$ & $29.86 \pm 5.55 \mathrm{abA}$ & $30.90 \pm 5.74 \mathrm{bA}$ & $30.27 \pm 5.62 \mathrm{bA}$ & $31.17 \pm 5.61 \mathrm{bA}$ & $31.37 \pm 5.84 \mathrm{bA}$ \\
\hline SRS2 & $29.77 \pm 5.56 \mathrm{aB}$ & $30.87 \pm 5.73 \mathrm{abA}$ & $31.07 \pm 5.77 \mathrm{abA}$ & $30.97 \pm 5.74 \mathrm{abA}$ & $32.30 \pm 5.90 \mathrm{abA}$ & $33.30 \pm 6.19 \mathrm{bA}$ \\
\hline LRS1 & $28.40 \pm 5.27 \mathrm{aA}$ & $30.30 \pm 5.63 \mathrm{abA}$ & $28.50 \pm 5.24 \mathrm{aA}$ & $32.37 \pm 6.01 \mathrm{bA}$ & $30.33 \pm 5.63 \mathrm{abA}$ & $33.47 \pm 6.21 \mathrm{bA}$ \\
\hline LRS2 & $27.27 \pm 5.07 \mathrm{aA}$ & $28.30 \pm 5.25 \mathrm{aA}$ & $28.37 \pm 5.29 \mathrm{aA}$ & $30.50 \pm 5.63 \mathrm{abA}$ & $30.20 \pm 5.47 \mathrm{aA}$ & $30.30 \pm 5.63 \mathrm{abB}$ \\
\hline
\end{tabular}

Means followed by the same small letter $(\mathrm{a}-\mathrm{b})$ within rows indicate that there is no significant difference on the effect of seasons and locations on larval duration across the strains $(\mathrm{P}$ $>0.05$ ) by Tukey's test.

Means followed by the same capital letter $(\mathrm{A}-\mathrm{B})$ within columns indicate that there is no significant difference on the effect of seasons and locations on larval duration within the same strain $(\mathrm{P}>0.05)$ by Tukey's test.

Table 2. Average Weight of $5^{\text {th }}$ Instar Larvae in Relation to Average Amount of Food Consumed in in Location 1 (S1) and Location 2 (S2)

\begin{tabular}{|c|c|c|c|c|}
\hline Strain & Location & Ave. Amount of Food Consumed (dry) CF (gms) & Ave. Weight of 5 $^{\text {th }}$ Instar Larvae LW (gms) & FC as \% of LW \\
\hline \hline C X Z & S1 & 3.84 & 4.40 & 4.20 \\
\hline & S2 & 3.64 & 4.31 & 87.27 \\
\hline Q X H & S1 & 3.69 & 4.18 & 86.67 \\
\hline Q X B & S2 & 3.57 & 4.25 & 85.60 \\
\hline & S1 & 3.69 & 3.72 & 86.41 \\
\hline 75xin & S1 & 3.53 & 3.51 & 86.10 \\
\hline & S2 & 3.17 & 4.10 & 85.21 \\
\hline S X M & S1 & 2.99 & 4.04 & 85.19 \\
\hline
\end{tabular}

\section{Quantity of Mulberry Consumed and the Amount of Silk Produced}

There was a relationship between the consumed food (CF) and the cocoon weight (CW). The more food consumed, the heavier the cocoon, ICIPE I had the highest CW, $\mathrm{CF}$ and cocoon shell weight (CSW) in locations $S 1$ and $S 2$. On the other hand 75xin had the least CW, CF and CSW. Table 3 shows the percentages of CW and CSW against the quantity of $\mathrm{CF}$ by the silkworm larvae. There is a wide variation among the 6 strains. The percentage of $\mathrm{CW}$ against $\mathrm{CF}$ ranged between $50-58 \%$, whereas that of the CSW was between $9-10 \%$. The relationship of the weight of cocoon shell and the amount of food consumed is important to determine which strain gives better percentage of silk production to the amount of mulberry leaves actually consumed.

Further comparative performance tests in the two locations showed that there was a significant difference in the means of cocoon, pupa and shell weight across the strains. 75xin had the lowest CW, PW and SW irrespective of the season and location, on the other hand ICIPE I had the high- est means in these same parameters in the two locations respectively. It is interesting to note that ICIPE I's mean cocoon, pupa and shell weight respectively, had no significant differences within the seasons and locations (Table 4).

\section{DISCUSSION}

In this study the newly hatched silkworms of all the strains were not active. This characteristic relates to observations in a similar study, where the activities of young larvae varied with the silkworm strain [18]. In the Chinese races, soon after hatching the young larvae do not move around but remain near the eggs. On the other hand, in the Japanese and European races, the young larvae are extremely active and move around. This behaviour is repeated even in advanced stages of the larvae.

Rearing of the silkworms was done in rearing trays and shoot rearing beds in both locations respectively. In location $S 1$, temperature and humidity was maintained at $26{ }^{\circ} \mathrm{C}$ and $85 \%$ for young age rearing and $24^{\circ} \mathrm{C}$ and $70 \%$ for late age rearing, respectively. Location $S 2$ temperature and humidity was between $24-27^{\circ} \mathrm{C}$ and $84-86 \%$, for the young age and 
Table 3. Relationship of Cocoon Weight and Cocoon Shell Weight to the Quantity of Consumed Food in Location 1 (S1) and Location 2 (S2)

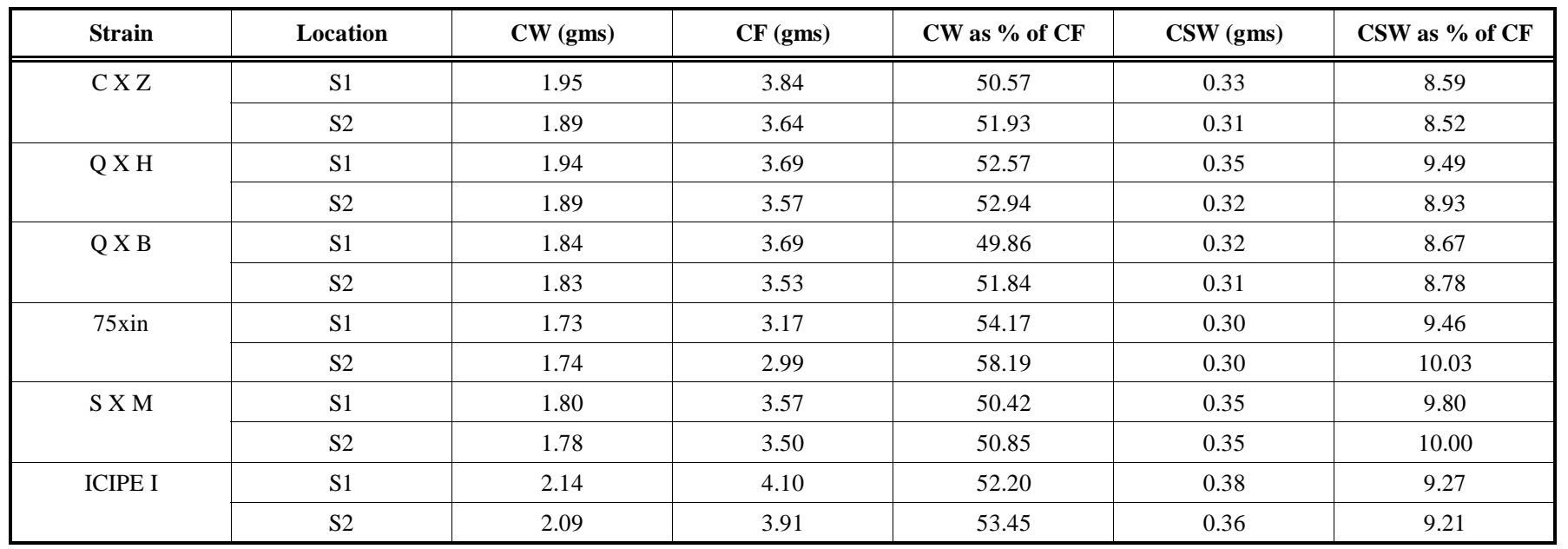

CW: Cocoon Weight; CF: Consumed Food; CSW: Cocoon Shell Weight.

Table 4. Comparative Performance of Cocoon, Pupa, Shell and Larval Weights (Expressed as Mean \pm SE)

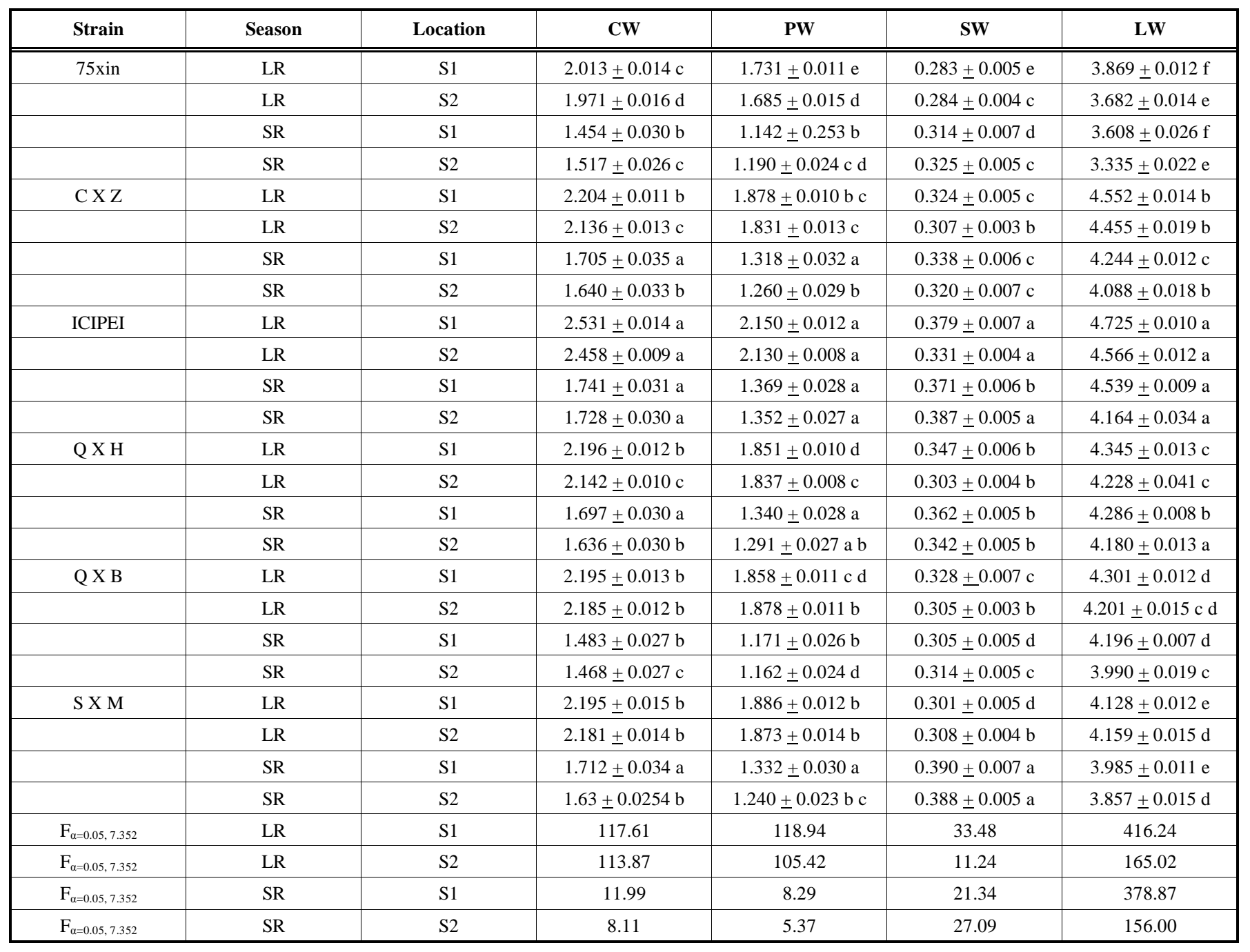

Means followed by same letters $(\mathrm{a}-\mathrm{f})$ within columns indicate there is no significant difference on the effect of season and location on the CW, PW. SW and LW across the strains ( $\mathrm{P}>0.05)$ by Tukey's test.

CW: Cocoon Weight; PW: Pupa Weight; SW: Shell Weight; LW: Larval Weight. 
$23-24{ }^{\circ} \mathrm{C}$ and $65-70 \%$. These two parameters relate to results of an earlier study done, that noted temperatures in the range of $21-27{ }^{\circ} \mathrm{C}$ with relative humidity (RH) of $70-85 \%$ are required for rearing [19]. It is worth to further note that the ability of silkworms to produce is affected by seasonal factors such as temperature and humidity, as verified by the silkworms reared in the two locations during the two seasons. It has been well established that efficiency in silkworm production is often lower during and after the hot season. One reason for the reduction in their productive performance might be elevated ambient temperatures, which induce heat stress [20]. Research has been performed on the use of a chawki-rearing technique named "Chawki Foam Pad Cover" developed at Central Research Station BAIF, to avoid unfavorable environmental conditions. This technique showed better growth, uniform moulting and better survival rate $(10 \%)$ during the chawki stage and ultimately, cocoon production. Optimum temperatures of $26 \pm 2{ }^{\circ} \mathrm{C}$ and humidity $80 \pm 5 \% \mathrm{RH}$ respectively, were maintained [21].

During the early age rearing silkworms were fed on chopped leaves and as they grew during the late age rearing they were fed on entire leaves. This was replicated in the two locations during the two seasons. The average mean larval weight of the silkworms reared in $S 1$ was $4.21 \mathrm{gms}$ and 3.8 in $S 2$. The larvae showed a steady larval mean weight increase, ICIPE I gaining a maximum larval mean weight of $4.73 \mathrm{gms}$. Studies on the effect of different feeding methods have been done and results indicate the entire leaf method showed better performance and indicated potential for field use [22].

The feed ratio was not restricted during the study, as previous studies have shown that there is no significant difference in the parameters. Studies have been carried out to evaluate larval performance when fed on different feeding ratios. They have revealed that all the parameters on the raw silk production data have no significant difference among treatments [23]. At the young larval stage the rearing conditions greatly affect the sericulture operation. Some of the important conditions are the quality of mulberry, temperature and humidity $\left(26-27^{\circ} \mathrm{C}\right.$ and $80 \%$ respectively). It is therefore important that there are minimal fluctuations of temperature and humidity $[18,14]$.

Under ideal conditions it has been reported that the total larval duration is $25-30$ days $[14,24]$. On the other hand it has also been observed that the $B$. mori silkworm completes cocoon formation in 24-28 days from the day of hatching [21]. Larval span in this study larval span was $29 \pm 3$ days among the strains in the two seasons and locations. These variations may have been due to differences in temperature and humidity in the two locations. On the other hand, the characteristics of the strains cannot be overlooked.

It has been documented in related studies that rearing temperature has an important influence on the efficiency of food utilization by larvae of the silkworm Bombyx mori L. During this study ICIPE I was able to convert the highest percentage of consumed food into its weight, 88.55 and $87.65 \%$ for locations S1 and S2 respectively. These percentages concur with results from a study that revealed silkworms utilize $85-88 \%$ of total leaf consumption during $5^{\text {th }}$ instar, ranging over a period of about 8 days [25]. Similarly, studies to assess food intake and utilization efficiency in $B$. mori reared at different temperature combinations viz. 26,
28,30 and $32^{\circ} \mathrm{C}$ during instars I to III and combinations of these temperatures during later instars (IV and V) have been performed. They have revealed that the amount of dry food consumed by silkworms reared at $28^{\circ} \mathrm{C}$ during young-age, than at the other temperatures was significantly higher, but a significant decrease in conversion efficiencies [26].

The relationship between the quantities of mulberry leaves consumed and the production of silk is important in sericulture. Even while selecting the races it is desirable to select those races, which produce higher quantity of silk per unit of feed consumed [18]. There was a wide variation among the strains during the study, the percentage of total cocoon weight for the amount of food consumed was between $50-58 \%$ whereas that of the cocoon shell weight was between 9 and $10 \%$. This relates to results of a similar study that noted a wide variation of $55-60 \%$ and $10-13 \%$ respectively and observed that the amount and percentage of assimilated food differed according to different environmental conditions during rearing [18]. It is also well known that the temperature and humidity as well as texture of the leaves have much influence on this aspect.

Cocoons obtained from S1 location were larger and heavier compared to those of S2 location except from 75xin, where interestingly, the reverse occurred but by a minor margin. It has been reported that Bombyx mori yields superior quality cocoons at optimum temperatures $\left(22-23^{\circ} \mathrm{C}\right)$ and humidity $(60-70 \%)$ [27]. Ventilation during spinning is crucial for a good cocoon quality $[18,25,28]$. These observations could be as a result of the conditions, which differed in $\mathrm{S} 1$ and S2. These results relate to reports that high temperature followed by strong fluctuation results in poor quality cocoons of B. mori [13].

One of the major constraints in silk cocoon production is the occurrence of diseases. It is imperative to note environmental factors and pathogens that may induce silkworm diseases. In Kenya, sericulture is a new venture and there has been no note of endemic diseases. On the other hand grasserie caused by a nuclear polyhedrosis virus has been noted as affecting silkworms during rearing and to a lesser extent pebrine caused by the microsporidan Nosema bombycis.

\section{CONCLUSION}

The quality characteristics of the cocoons depend on race (strain) of silkworms, rearing technology and atmospheric conditions maintained during silkworm rearing and cocoon spinning stage. In conclusion, we can report that ICIPE I and CXZ strains performed well compared to the other strains and are ideal for silk production in the Kenyan fields.

\section{ACKNOWLEDGEMENTS}

We would like to thank Regina Macharia and Mary Kahinya for the technical support in the laboratory experiments. We wish to thank the International Fund for Agricultural Development (IFAD) for the research grant and icipe management for their support.

\section{REFERENCES}

[1] Tsukada M, Islam S, Arai T, Bosch A, Fred G. Microwave irradiation technique to enhance protein fiber properties. Autex Res J 2005; 5(1): 40-8.

[2] Lee YW. Silk reeling and testing manual. FAO Agricultural Services Bulletin No. 136. Rome, Italy 1999. 
[3] Zhao Y, Chen K, He S. Key principles for breeding spring-andautumn using silkworm varieties: from our experience of breeding 873×874. Caspian J Environ Sci 2007; 5(1): 57-61.

[4] Thapa RB, Ghimire NP. Performance of mulberry silkworm (Bombyx Mori L.) under leaf and shoot feeding methods. J Inst Agric Anim Sci 2005; 26: 83-6.

[5] Shekharappa BM, Gururaj CS, Raghuraman R, Daandin SB. Shoot feeding for late age silkworms. Karnataka State Sericulture Development Institute: Banglore, India 1993.

[6] Hirobe T. Characterization of silkworm races. Proceedings of International Congress of Genetics 1968.

[7] Thapa RB, Shrestha KB. Silkworm rearing technology. Paper presented at the Workshop on Appropriate Sericulture Technology, Nagarkot, Bhaktapur, Nepal 1999.

[8] Ghimire N. Sericulture: the context in Nepal. Paper presented at the National Workshop of Plant Protection Officers, Department of Agriculture, Kathmandu, Nepal 2000.

[9] Adolkar VV, Raina SK, Kimbu DM. Evaluation of various mulberry Morus spp. (Moraceae) cultivars for the rearing of the bivoltine hybrid race Shaanshi BV-333 of the silkworm Bombyx mori (Lepidoptera: Bombycidae). Int J Trop Insect Sci 2007; 27(1): 6-14.

[10] Boraiah G, Ed. Establishment of germplasm bank of mulberry and evaluation of mulberry varieties. Suramya Publishers, Bangalore, India 1986.

[11] Urs R. Role of grainage in silk industry in India. Paper presented at the trainers' course and third international workshop on the conservation and utilization of commercial insects, $13^{\text {th }}$ Nov $-8^{\text {th }}$ Dec 2000. SK Raina, EK Nguku, Eds. ICIPE Science Press Nairobi, Kenya 2005.

[12] Jolly MS, Ed. Appropriate sericulture techniques ICTRETS, Mysore, India 1987; p. 75.

[13] Ullal SR, Narasimhanna MN. Handbook of practical sericulture. $3^{\text {rd }}$ ed. Central Silk Board, Bangalore, India 1987; p. 166.

[14] Raina SK, The Economics of sericulture and apiculture modules for income generation in Africa. IBRA, UK 2000; p. 86.

[15] Devaiah MC, Reddy DNR. Sericulture - An overview. In: Devaiah MC, Narayanaswamy KC, Maribashetty VG, Eds. Advances in mulberry sericulture. CVG. Publications, Bangalore 1999; pp. 1-16.
[16] Miyashita Y. A report on mulberry cultivation and training methods suitable to bivoltine rearing in Karnataka 1986; pp. 1-7.

[17] Minamizawa K. Moriculture - Science of mulberry cultivation 440; A.A. Balkema, Rotterdam 1997; 27(1): 431.

[18] Aruga H. Principles of sericulture. Oxford and IBH publishing Co. Pvt. Ltd, 66 Janpath New Delhi, India 1994; p. 376.

[19] Tazima Y. The Silkworm an important laboratory tool. Kodansha Ltd: Tokyo, Japan 1978.

[20] Lertsatitthanakorn C, Rerngwongwitaya S, Soponronnarit S. Field experiments and economic evaluation of an evaporative cooling system in a silkworm-rearing house. Silsoe Research Institute. Elsevier Ltd 2006.

[21] Singh KK, Dhepe VS, Jadhav DV, Dusane SE, Gokhale SB. A new technique of summer season chawki rearing of silkworm Bombyx mori (L). BAIF Dev Res Found 2002.

[22] Dhepe VS, Singh KK, Gokhale SB, Jadhav DV. Performance of silkworm Bombyx mori (L) by different feeding methods under Western Maharashtra Conditions. BAIF Dev Res Found 2000.

[23] Tejano NM, Sanchez ZL, Abragan HC. Performance of F1 silkworm hybrid (Mol 251 X KI 51) to raw silk production 2002.

[24] Lim SH, Kim YT, Lee SP, Rhee IJ, Lim JS, Lim BH. Sericulture Training Manual. FAO Agric Serv Bull Rome 1990; 80: 117.

[25] Krishnaswami S, Narsinhanna MN, Suryanarayan SK, Kumaraji S. Manual on sericulture II: silkworm Rearing. FAO Agric Serv Bull AGS 1973; 22(15): 1-131.

[26] Muniraju E, Sekharappa BM, Raghuraman R. Food intake and utilization efficiency in silkworm Bombyx mori L. (Pure Mysore) reared at different temperature combinations. Int J Trop Insect Sci Cambridge University Press 2004; 24: 135-42.

[27] Yokoyama T. Synthesized science of sericulture, Central Silk Board, Bombay 1962; 24(2): p. 378.

[28] Indiaagronet [homepage on the Internet]. Management of rearing, mounting and production of cocoon - Sericulture. [cited 2008 February1] Available from: http://www.indiaagronet.com/

(C) Nguku et al.; Licensee Bentham Open.

This is an open access article licensed under the terms of the Creative Commons Attribution Non-Commercial License (http://creativecommons.org/licenses/by-nc/3.0/) which permits unrestricted, non-commercial use, distribution and reproduction in any medium, provided the work is properly cited. 